\title{
Study of the effect of institutional ownership on accounting quality and cost of capital
}

\section{Estudio del efecto de la propiedad institucional sobre la calidad contable y el costo de capital}

\author{
Reza Fallah \\ Masters of Business management-finance \\ ORCID: https://orcid.org/0000-0001-7260-9729
}

Received 09-08-20 Revised 10-10-20 Accepted 20-12-21 On line 03-01-21

* Correspondence

Email: rezafallah.business@gmail.com
Citation:

Reza Fallah (2021). Study of the effect of institutional ownership on accounting quality and cost of capital. Propósitos y Representaciones, 9(SPE2), e1053. http://dx.doi.org/10.20511/pyr2021.v9nSPE2.1053 


\begin{abstract}
This study was conducted to investigate the effect of institutional ownership on accounting quality and cost of capital. This research is quasi-experimental in the field of positive accounting research and based on real information in the financial statements of companies. It is also of correlational type and, it is a descriptive (comparative / analytical) research in terms of data collection method. The research methodology is post-event due to the use of historical information in terms of time, and because it can be used in the process of using information and can be used in practice, it is a kind of applied research. The statistical population of the present study includes all companies listed on the Tehran Stock Exchange, with the exception of banks and financial and credit institutions, investment companies, financial intermediaries, holding companies and leasing companies (which have different financial structure and management principles than other companies). The information of these companies for the 7-year period from 2011 to 2017 has been studied. In order to examine the relationship between institutional ownership and quality of accounting information and cost of capital debt and to examine the moderating role of institutional ownership in the relationship between quality of accounting information and cost of capital debt, regression analysis was presented. Also, in the regression analysis, the generalized regression model was fit, and the coefficients of regression variables were estimated. In addition, the test of zero regression coefficients for the significance of the model and each of the variables was performed. The test results of the research hypotheses showed that there is a significant relationship between institutional ownership and quality of accounting information and cost of capital debt, but institutional ownership has not been able to moderate the relationship between quality of accounting information and cost of capital debt.
\end{abstract}

Keywords: Institutional Ownership, Accounting Quality, Cost of Capital.

\title{
Resumen
}

Este estudio se realizó para investigar el efecto de la propiedad institucional sobre la calidad contable y el costo de capital. Esta investigación es cuasi-experimental en el campo de la investigación contable positiva y se basa en información real en los estados financieros de las empresas. También es de tipo correlacional y es una investigación descriptiva (comparativa / analítica) en términos de método de recolección de datos. La metodología de investigación es postevento debido al uso de información histórica en términos de tiempo, y porque puede usarse en el proceso de uso de información y puede usarse en la práctica, es una especie de investigación aplicada. La población estadística del presente estudio incluye todas las empresas que cotizan en la Bolsa de Valores de Teherán, con la excepción de los bancos y las instituciones financieras y de crédito, las empresas de inversión, los intermediarios financieros, las sociedades de cartera y las sociedades de leasing (que tienen una estructura financiera y principios de gestión diferentes a otros compañías). Se ha estudiado la información de estas empresas para el período de 7 años de 2011 a 2017. Con el fin de examinar la relación entre la propiedad institucional y la calidad de la información contable y el costo de la deuda de capital y examinar el papel moderador de la propiedad institucional en la relación entre la calidad de la información contable y el costo de la deuda de capital, se presentó un análisis de regresión. Asimismo, en el análisis de regresión se ajustó el modelo de regresión generalizado y se estimaron los coeficientes de las variables de regresión. Además, se realizó la prueba de coeficientes de regresión cero para la significancia del modelo y cada una de las variables. Los resultados de las pruebas de las hipótesis de investigación mostraron que existe una relación significativa entre la propiedad institucional y la calidad de la información contable y el costo de la deuda de capital, pero la propiedad institucional no ha podido moderar la relación entre la calidad de la información contable y el costo de la deuda de capital.

Palabras clave: propiedad institucional, calidad contable, costo de capital.

\section{Introduction}


There is growing research showing that corporate governance mechanisms are an effective way to improve quality of financial reporting. Most research has shown that good corporate governance mechanisms provide more oversight of the financial reporting process or related profits that are more informative. Corporate governance is the system by which companies are guided and controlled. The board of directors is responsible for the governance of the company. The role of shareholders in governance is to determine and appoint all managers and auditors in the company to reassure them that the desired governance structure is in place in the company. Corporate governance is a term that did not make much sense to others a decade or two ago, except for a few researchers and shareholders, but now it is a key issue for board of directors of companies, academic conferences and political roundtables throughout the world. Voluntary disclosure of information is disclosure of information beyond the legal obligations established by the legislature. Voluntary disclosure of information is the process of obtaining information from the reporting company to the financial markets. Companies that voluntarily disclose information that there is no obligation for them to be provided from the legislature. A review of corporate governance literature introduces five quantifiable mechanisms of corporate governance that can be calculated and are available in Iran's economic and national environment and conditions, which are expected to have a significant relationship with earnings management and include internal mechanisms of corporate governance, including independence of board members, separation of the of the CEO from the chairman of the board of directors, and external mechanisms of corporate governance, including institutional shareholders (Christie and Zimmerman, 1994). Semantically, the word disclosure means the dissemination of information, but accountants often tend to use this term in a limited way, meaning to disseminate purely financial information of a business unit in annual reports. Determining the amount of information that can be provided depends on the goals of financial reporting and the importance of the items. The purpose of financial reporting is to provide information to potential investors, creditors, and other users, so that the information is useful in rational investment decisions, accreditation, and similar decisions (Hendriscsen \& wen berda, 1992). On the other hand, factors such as earnings management increase information asymmetry and agency contradictions. In general, earnings management is possible in two ways: earnings management based on accounting figures and real earnings management. In the first case, the management, through discretionary accruals, arranges accounting figures in accordance with its desired objectives. But in the second case, the management achieves the desired profit by making some operational decisions, in other words, manipulating the actual activities to actually manage the profits.

Accounting has a social nature that grows and develops and emphasizes the support of actual and potential investors by separating ownership from management. To control fictitious accounting, most countries have emphasized the concept of disclosure and transparency. Disclosure is the most important part of corporate governance. The clearer and more accurately the company's internal operations and cash flow are reported, the more limited the grounds for embezzlement and mismanagement for managers and major shareholders. The most important issue in the field of information disclosure is that all factors affecting stock prices must be reported at the right time with sufficient accuracy (Goodarzi, 2008).

\section{Research objectives}

\section{Main objective}

- Studying the effect of institutional ownership on accounting quality and cost of capital

\section{Sub-objectives} information

- Determining the relationship between institutional ownership and quality of accounting

- Determining the relationship between institutional ownership and costs of capital

- Determining the relationship between quality of accounting information and costs of capital 


\section{Research background}

Garmei and Asadollahi (2017) examined the effect of institutional ownership on the relationship between quality of accounting information and the company's investment options. Investment is one of the economic and financial issues and one of the important factors in solving economic problems of countries. However, this alone is not enough, and given the limited financial resources, in addition to the issue of investment development, increasing the adequacy of investment is also an important issue. In addition, the adequacy of investment or optimal investment requires, on the one hand, to prevent the consumption of resources in activities in which the investment has been made too optimally, and on the other hand, the resources be directed to activities that need more investment. The purpose of this study was to investigate the effect of institutional ownership on the relationship between quality of accounting information and investment options of companies. In this study, first the concept of investment and its types were discussed, then the efficiency and inefficiency of investment and the relationship between quality of reporting and investment efficiency were described. To measure quality of information, three criteria of earnings smoothness, earnings predictability and quality of accruals were used. Finally, the concept of institutional ownership and its impact on corporate performance was expressed. Based on the research results, we find that in companies with higher earnings smoothness and higher quality of accruals, investment in the main activity is higher and also the level of institutional ownership has a significant impact on the relationship between the earnings smoothness and quality of accruals and the amount of investment in the main activity of the company.

Hassanvand (2016) examined accounting information, cost of capital and excess stock returns, emphasizing the role of profit quality in companies listed on the stock exchange. Financial reporting is considered as one of the most important information structures in securities markets and the quality of the figures provided, especially the quality of profits, plays an important role in meeting the needs of actual and potential shareholders of the business unit. Therefore, accounting information, and in particular the quality of profits, is expected to affect the minimum rate of return expected by investors (cost of capital) and ultimately correlate with the excess returns of shareholders. Therefore, this study seeks to empirically examine the relationship between accounting information and excess stock returns for a sample with 123 companies listed on the Tehran Stock Exchange, with a regression approach based on hybrid analysis for the years 2006 to 2010. The findings show that there is a significant relationship between accounting information and cost of capital, and especially the quality of profits as an important element of financial reporting has a negative and significant relationship with cost of capital. The findings also show that cost of capital is inversely related to shareholders' excess returns. These findings re-emphasize the usefulness of accounting figures, especially the quality of profits on cost of capital and excess return per share.

Qatebi and Shamshiri (2017) examined the relationship between institutional ownership, managerial ownership and cost of capital of companies listed on the Tehran Stock Exchange. The purpose of the present study is to investigate the relationship between institutional ownership, managerial ownership and cost of capital in 96 companies listed on the Tehran Stock Exchange over a six-year period from 2010-2015. In this study, the dependent variable is cost of capital, which is measured by the two criteria of debt cost and equity cost; also, the independent variables used in the present study are institutional ownership and managerial ownership. Based on the existing theoretical foundations, four hypotheses have been formulated that a multivariate regression model and a conventional panel have been used to investigate this relationship. The results of the first hypothesis test indicate the existence of a negative and significant relationship between institutional ownership and equity cost. Also, the results of the second hypothesis test indicate the existence of a negative and significant relationship between managerial ownership and equity cost; also, the results of the first hypothesis test indicate the existence of a negative and significant relationship between institutional ownership and debt cost, and finally the results of the second hypothesis test indicate the existence of negative and significant relationship between managerial ownership and debt cost. 
Jafari and Mottaghi (2016) examined institutional ownership and earnings management: the moderating role of auditing quality. The dependent variable of this research is earnings management and its independent variable is institutional ownership. Also, in this study, audit quality has been used as a moderator variable. To measure auditing quality, two criteria of auditor size and auditor expertise in the industry have been used. The statistical population of this study is from the companies listed on the Tehran Stock Exchange, which, after considering the conditions, 611 companies have been selected as the research sample. The research period is 7 years, and the required data has been extracted from the audited financial statements and other sample member reports. Integrated least squares regression was used to test the hypotheses. The main finding of this study is that there is a significant relationship between institutional ownership and earnings management, but auditing quality does not affect the relationship between institutional ownership and earnings management.

Alimardi (2016) examined the impact of institutional ownership and corporate debt on auditing quality in the Iranian capital market. Despite the expansion of ownership and the number of shareholders, the control and management of companies has been given to a specific group of shareholders. Because most of the company's shares are bought and sold by investors with the aim of making a profit in the short term, this has practically reduced the influence of shareholders except in selecting the company's board of directors and monitoring their performance, and has made companies be controlled and directed by specific stakeholders. This group of shareholders plays a key role in determining the majority of board members, selecting an independent auditor, and determining the overall policy of the company. In this study, the impact of institutional ownership and company debts on auditing quality in the Iranian capital market has been investigated. This research is correlational in terms of method and nature. It is hybrid in terms of the relationship between the variables, quantitative in terms of the type of data, descriptive-survey in terms of implementation, and retrospective in terms of time and applied in terms of purpose. The panel data method was used to estimate the model. The statistical population of this study is the companies listed on the Tehran Stock Exchange. In the period from 2009 to 2013, 64 companies were selected based on systematic sampling. Multivariate statistical and regression tests were used to conduct this study. The results of the research hypothesis analysis using EViews software indicate that the first and second main hypotheses confirm the relationship between institutional ownership and corporate debts on auditing quality and due to the negative signs of institutional ownership and corporate debts, the relationship of this variable with auditing quality is reversed.

Hsieh et al. (2019) examined the relationship between institutional ownership and accounting quality and cost of capital with the panel smooth transition regression approach. In this study, we examined any significant changes in the relationship between accounting quality and cost of capital, which may be related to institutional ownership. Our analysis includes a flexible econometric approach based on "panel smooth transition", the regression analysis (PSTR) was performed using data from 64 companies listed in Taiwan between 2000 and 2010. The results show that the relationship between accounting quality and cost of capital is actually different from changes in institutional ownership, a finding which, having relaxed the assumption that the interpretations of accounting information amongst investors are homogeneous, goes beyond the general finding within the extant literature of a linear relationship between accounting quality and cost of capital.

Gray et al. (2018) examined the relationship between quality of accrual accounting, information risk and capital prices: evidence from Australia. The results show that information risk is a non-diversifiable risk factor that is priced in the capital market. Using accruals quality to proxy for information risk, Francis et al. (2005) provide empirical support for this argument using a sample of US firms. This paper re-examines the interplay of accruals quality, information risk and cost of capital in Australia, where a number of important institutional and regulatory differences are hypothesized to affect the relation between accruals quality and cost of capital. The results suggest that, while accruals quality impacts on cost of capital for Australian firms, some salient differences exist. In contrast to findings for US firms, costs of debt and equity for Australian firms are largely influenced by accruals quality arising from economic fundamentals (i.e., innate accrual quality) but not discretionary reporting choices (i.e., discretionary accrual quality). This finding is 
consistent with the predictions based on the Australian institutional and regulatory environment. In addition, using both the asset pricing tests in Francis et al. (2005) and Core et al. (2008), evidence is provided which is consistent with accruals quality being a priced risk factor.

Anagnostopoulou and Tsekrekos (2015) examined accounting quality, information risk and implied volatility around earnings announcements. Uncertainty about the future economic performance of firms, as well as the low quality of profits (which is considered as a proxy variable of information risk), is expected to affect the volatility of their stock returns. In this study, we examined the relationship between quality of accounting reporting (which is measured by assessing quality of accounting accruals) and the level and changes in implied volatility around quarterly earnings announcements in trading options markets. In line with previous research, we have used accounting accruals as a proxy variable of firm risk information. Since accruals quality is expected to inform investors about the mapping of accounting earnings into cash flows, it is expected that the low quality of accruals will reduce this mapping and thus increase the risk of information.Our analysis was also based on an article by Rajgopal and Venkatachalam (2011) that distinguish between sources of uncertainty about the firm's future profitability (or uncertainty about future cash flows from an operational perspective) and information on future cash flows resulting from quality of accounting information

Oxio et al. (2017) examined the accounting quality of Chinese firms: the impact of ownership structure. The purpose of this paper is to examine the impact of ownership structure on the accounting quality of firms listed on the Chinese stock market, an area where little research has been done. Through experimental tests on the four existing criteria of quality for 1438 firms listed on the Shenzhen and Shanghai stock exchanges during the period 1999 to 2006, we found that although the size of state-owned firms (which account for approximately three-quarters of all firms registered in China) is larger and they seem more profitable, private, foreign, and social firms in the field of earnings quality, which through profit volatility, profit variability relative to cash flows, the correlation among accruals and cash flow, and discretionary accruals was measured, performed better than government-controlled firms. This is not surprising because the controller of state-owned firms, the State Property Management Office, has neither the motivation nor the ability to monitor listed firms, while non-governmental firms operate on the basis of market mechanisms. The results also show that foreign firms have the highest profit quality among all types of ownership structure groups, and firms owned by employees exercise the most caution in profit management, ranking fourth in four profit quality tests. In addition, although mass-owned firms are claimed to have more operational efficiency, we have not seen any significant improvement in the quality of their profits.

Sun et al. (2016) examined institutional ownership, capital structure, and financing decision: evidence from the United Kingdom. This study expands our knowledge of capital structure in the following ways. First, this study emphasizes the importance of the relationship between leverage and ownership in the UK. Our analysis uses two major proxies for ownership: MSO and institutional ownership. Our empirical results show a non-monotonic relation between MSO and the debt ratio. At lower MSO levels, the relation with leverage is positive, supporting interest alignment theory. This is because higher managerial ownership plays an important role in aligning the interests of corporate managers and shareholders, leading to lower costs of debt. In this case, firms are likely to raise more debt, resulting in higher debt. However, this relation becomes negative for a small proportion of higher-MSO firms, which can be explained by the managerial entrenchment hypothesis. Corporate managers who own high percentages of firm shares are in a better position to protect their private interests from the risk of bankruptcy associated with a high leverage ratio. Our finding is consistent with the studies of Brailsford et al. (2002) and Florackis and Ozkan (2009). The results that institutional ownership has a homogeneously positive effect on firm leverage ratios, although a high degree of institutional ownership decreases the probability of issuing bonds over equity. Our results provide two explanations: First, high institutional OC firms have an incentive to issue more bonds and less equity. Second, such firms are more likely to turn to other types of debt as financing channels. 
Karanovic and Gjosevska (2016) examined the application of fuzzy logic in determining cost of capital for the capital budgeting process. As it is shown in this paper, vagueness and uncertainty are main characteristic of capital budgeting process and also of the associated process of the determination of cost of capital. Comparing the most commonly used methods for determining cost of capital, it can be concluded that fuzzy logic and triangular fuzzy numbers should be recommended, or even yet and obligatory tool for estimating cost of capital in small and undeveloped markets for determining cost of capital. Since that with using fuzzy logic and triangular fuzzy numbers it is possible to apply qualitative information as linguistic variables and used them for quantitative process of determining cost of capital.

According to the extensive studies mentioned in this chapter, research on institutional ownership has been conducted, but so far research has not been conducted on the effect of institutional ownership on accounting quality and cost of capital. Therefore, the present study is innovative in terms of subject matter and goals.

\section{Research implementation method}

This research is quasi-experimental in the field of positive accounting research and based on real information in the financial statements of companies. It is also of correlational type and, it is a descriptive (comparative / analytical) research in terms of data collection method. The research methodology is post-event due to the use of historical information in terms of time, and because it can be used in the process of using information and can be used in practice, it is a kind of applied research.

To test the research hypotheses, multivariate linear regression analysis was used. Regressions at the level of year-company are used to examine the research model. The regression method used is the panel method. First, the appropriate method is selected to fit the model. Using F-Limer Hausman test and studying the collinearity between model variables, between simple linear regression method, simple linear regression method with time factor, fixed effects panel method, random effects panel method and integrated data panel method, the appropriate method is chosen to fit the model and after fitting the model, the coefficients are estimated and their significance is reported.

\section{Research hypotheses}

In order to achieve the objectives of the research and according to the theoretical foundations, the research hypotheses have been designed and developed as follows:

Hypothesis 1: There is a significant relationship between quality of accounting information and cost of capital debt.

Hypothesis 2: There is a significant relationship between institutional ownership and cost of capital debt.

Hypothesis 3: Institutional ownership moderates the relationship between quality of accounting information and cost of capital debt.

\section{Statistical population and sampling method}

The statistical population of the present study includes all companies listed on the Tehran Stock Exchange, with the exception of banks and financial and credit institutions, investment companies, financial intermediaries, holding companies and leasing companies (which have different financial structure and management principles than other companies). The information of these companies is examined for the period of seven years from 2011 to 2017. (2011 and 2012, because for the calculation of some variables, the data of the previous year are needed (for example, change of accounts receivable and due to the delay of the information quality variable) has been considered, but the research models are fit for the period of five years between 2013 to 2017).

The statistical sample of this study is selected by screening of the statistical population, so that only companies that have the following conditions are examined in this study: 
1. During the years studied in this research, the trading symbols of the companies have not been removed from the stock exchange board.

2. In order to homogenize the statistical sample in the studied years, they have been accepted in Tehran Stock Exchange before 2012.

3. In terms of increasing the comparability, their financial periods lead to March 19 th.

4. There is no change in their activity or change in their financial years during the financial years in question.

5. The desired data is available.

6. There is no trading halt for more than 3 months in the case of shares of companies.

Table 1. Final sample size

\begin{tabular}{|c|c|}
\hline Feature & Number \\
\hline Total number of companies listed on the stock exchange at the end of 1396 (2017) & 377 \\
\hline $\begin{array}{c}\text { Number of companies that were not active in the stock market in the period of 1391- } \\
1396 \text { (2012-2017) and did not have a trading halt of more than three months. }\end{array}$ & $(76)$ \\
\hline $\begin{array}{c}\text { Number of companies that has been listed on the stock exchange after 1390 (2011). } \\
\text { Number of companies that have been part of holdings, investments, financial } \\
\text { intermediaries, banks or leasing companies. }\end{array}$ & $(38)$ \\
\hline $\begin{array}{c}\text { Number of companies that have changed their financial year in the period of 1390- } \\
1396 \text { (2011-2017). }\end{array}$ & $(11)$ \\
\hline Number of companies whose financial years do not lead to the end of Esfand (March). & $(59)$ \\
\hline $\begin{array}{c}\text { Number of companies whose research information was either not available or was } \\
\text { incomplete at the time interval. }\end{array}$ & $(3)$ \\
\hline Number of sample companies & 109 \\
\hline
\end{tabular}

Due to the limitations mentioned in the table above, 109 companies were selected as the final sample size.

\section{Information collection method}

Information plays an important role in conducting research and drawing the right conclusions from research. In this research, information and data have been extracted and collected as follows:

- Information on research literature and theoretical topics from library sources and scientific databases and foreign and domestic articles.

- Financial and performance data of companies from the Rahnavard Novin software and the websites of Tehran Stock Exchange Technology Management Company, Tehran Stock Exchange Technology Management Company, Islamic Research, Development and Studies Center of the Stock Exchange and Securities Organization and Comprehensive Publishers Information System (Codal).

The research variables were calculated using the Excel spreadsheet and the results were used as input to the Eviews software, and statistical analysis was performed using this software.

\section{Hypothesis test model}

In order to test the research hypotheses, the model 3-1 has been used as follows. Equation 1

$$
\text { Cost of Debt } \mathrm{i}_{\mathrm{i}, \mathrm{t}}=\beta_{0}+\beta_{1} \mathrm{AQ}_{\mathrm{it}-1}+\beta_{2} \mathrm{IQ}_{\mathrm{t}}+\beta_{3} \mathrm{AQ}_{\mathrm{t}-1} \times \mathrm{IQ}_{\mathrm{it}}+\beta_{4} \mathrm{r}_{\mathrm{m}, \mathrm{t}}+\beta_{5} \mathrm{SMB}_{\mathrm{t}}+\beta_{6} \mathrm{HML}_{\mathrm{t}}+\varepsilon_{i t}
$$

Cost of Debt $\mathrm{i}_{\mathrm{i}, \mathrm{t}}$ : Cost of capital debt

$\mathrm{AQ}_{\mathrm{it}-1}$ : Quality of accounting information

$\mathrm{IQ}_{t}$ : Institutional ownership ownership

$\mathrm{AQ}_{\mathrm{t}-1} \times \mathrm{IQ}_{\mathrm{it}}$ : Interactive effect of accounting information quality with institutional 
$\mathrm{r}_{\mathrm{m}, \mathrm{t}}:$ Market risk premium

$\mathrm{SMB}_{\mathrm{t}}$ : Size factor

$\mathrm{HML}_{\mathrm{t}}$ : Factor of book value to market value of equity

$\varepsilon_{i t}$ : Model error

In the above model, if the coefficients of the variables accounting quality, institutional ownership and interactive effect of accounting information quality with institutional ownership $\left(\beta_{1}\right.$ to $\beta_{3}$ ) are significant at the level of $5 \%$ error, the relevant hypothesis is confirmed.

\section{Research variables}

The dependent, independent, and control variables of the study are as follows:

The dependent variable

Cost of capital debt

The dependent variable of the research is cost of capital debt. Cost of capital debt is calculated by dividing the cost of interest by the sum of interest-bearing debts (total short-term and long-term financial facilities).

\section{The dependent variable}

The independent research variables include quality of accounting information, institutional ownership, and the interactive effect of accounting information quality with institutional ownership.

\section{Quality of accounting information}

The criterion quality of accounting information is quality of discretionary accruals. To calculate discretionary accruals, you must first calculate the total accruals in the desired year. After calculating the total accruals, non-discretionary accruals are calculated using the adjusted model of Jones (2005), and finally, discretionary accruals are obtained by deducting non-discretionary accruals from the total accruals.

$$
\frac{T A_{i t}}{\text { Assets }_{\text {it-1 }}}=\beta_{1} \frac{1}{\text { Assets }_{\text {it-1 }}}+\beta_{2} \frac{\Delta \text { Sales }_{\text {it }}-\Delta \mathrm{AR}_{\mathrm{it}}}{\text { Assets }_{\mathrm{it}-1}}+\beta_{3} \frac{\mathrm{PPE}_{\mathrm{it}}}{\text { Assets }_{\mathrm{it}-1}}+\varepsilon_{\mathrm{it}}
$$

Equation 2

$\mathrm{TA}_{\mathrm{it}}$ : It represents the total accruals of company $\mathrm{i}$ at the end of year $\mathrm{t}$, which is calculated from the difference between net profit and operating cash flow.

$\Delta$ Sales $_{i t}$ : Change in revenues of company $i$ in year $t$

$\triangle \mathrm{AR}_{\mathrm{it}}$ : Change in net trade accounts receivable of company $\mathrm{i}$ in year $\mathrm{t}$

$\mathrm{PPE}_{\mathrm{it}}$ : Gross property, machinery and equipment of company $i$ at the end of year $t$

Assets $_{i t-1}$ : Total assets of company i at the end of year $\mathrm{t}-1$

$\varepsilon_{\mathrm{it}}$ : Model error, or error term, actually indicates the estimated value of discretionary accruals used to represent quality of accounting information in the model.

\section{Institutional ownership}

Institutional ownership is the ratio of total shares in the authority of banks and insurance companies, holdings, investment companies, pension funds, financing companies and investment funds, government organizations and institutions, and state-owned companies to the company's total issued shares. If this ratio is greater than the median of total institutional ownership ratios, it takes one, else zero.

Interactive effect of accounting information quality with institutional ownership

Interactive effect of accounting information quality with institutional ownership is calculated from the product of two variables: interactive effect of accounting information quality and institutional ownership. 


\section{Control variables}

According to the research literature, in this research, some variables have been controlled as follows in order to control their effects on the relationship between independent and dependent variables.

The control variables include the market risk factor, the size factor and the ratio of book value of equity to market value of equity. Since these variables are defined after the steps, it is explained how to create these variables. First, portfolios are formed based on the size of the company and the ratio of the book value of equity to the market value of equity; in this way, the companies are divided into two portfolios of large companies and small companies based on size (total assets of the company at the beginning of the year), and in the next step, these companies, which are divided into two large and small portfolios, are divided into three portfolios of companies with high book value to stock market value ratios, companies with medium office value to stock market value ratios, and companies with low value market value to stock market value ratios based on the ratio of book value to market value (book value of equity divided by market value of equity at the beginning of the period). Six portfolios are formed from the interaction of the two factors of company size and the ratio of book value to market value of equity. In the following, how to measure each factor according to these portfolios is described.

\section{A) The $H M L$ variable}

The HML variable is the difference between the simple average return of two portfolios with high ratio of book value to stock market value $(\mathrm{BH}, \mathrm{SH})$ and the simple average return of two portfolios with low ratio of book value to stock market value (SL, BL):

3

$$
\mathrm{HML}=\frac{1}{2}(\mathrm{BH}+\mathrm{SH})-\frac{1}{2}(\mathrm{SL}+\mathrm{BL})
$$

Equation

As a result, $H M L$ is the difference between the monthly returns of portfolios with high ratio of book value to market value and low ratio of book value to market value in which the size is considered the same. Therefore, instead of focusing on the size factor in return, $H M L$ focuses on different trends (behaviors) of return in stock with high ratio of book value to stock value and stock with low ratio of book value to market value.

\section{B) The $S M B$ variable}

The $\boldsymbol{S M B}$ variable is the difference between the average return of 3 small-sized portfolios $(S H \cdot S M ، S L)$ and the average monthly return of 3 large-sized portfolios $(B H, B M \cdot B L)$.

$$
\mathrm{SMB}=\frac{1}{3}(\mathrm{SH}+\mathrm{SM}+\mathrm{SL})-\frac{1}{3}(\mathrm{BH}+\mathrm{BM}+\mathrm{BL})
$$

Equation 4

Therefore, $S M B$ is the difference between the average monthly return of small-sized portfolios and large-sized portfolios. Thus, instead of focusing on the ratio of book value to stock market, $S M B$ focuses on difference in trends (behaviors) of return on stock with small size and stock with large size.

\section{C) The $\mathrm{r}_{\mathrm{m}, \mathrm{t}}\left(\boldsymbol{R}_{M}-\boldsymbol{R}_{F}\right)$ variable}

The $R_{M}-R_{F}$ variable is market value premium. $R_{M}$ is expected market return, which is obtained from the return of 6 portfolios per month. $R_{F}$ is risk-free rate of return that bank interest rate for each year has been used in this research.

\section{Descriptive statistics of the research variables}

The first step in statistical analysis is to determine the abbreviated specifications of the data and to calculate the descriptive indicators. The purpose of this analysis is to identify the internal 
relationships of the variables and to show the behavior of the subjects so that the basics of their analysis can be provided and descriptive features can be revealed for further analysis. Information related to the descriptive statistics, including dependent variables, main and control variables, has been collected from 5-year data of companies (2013-2017). The results of descriptive statistics for quantitative and qualitative variables of the research are presented in Tables 2 and Table 3, respectively. The descriptive statistics of quantitative variables indicate the descriptive parameters for each variable separately. These parameters mainly include information about central indicators, such as minimum, maximum, mean, median, as well as information of dispersion indicators, such as standard deviation. The most important central indicator is mean, which indicates the equilibrium point and the center of gravity of distribution and is an appropriate indicator to show the centrality of the data.

Table 2. Descriptive statistics of quantitative variables

\begin{tabular}{|c|c|c|c|c|}
\hline Variable & Minimum & Maximum & Mean & $\begin{array}{c}\text { Standard } \\
\text { deviation }\end{array}$ \\
\hline Cost of capital debt & 0.000 & 5.157 & 0.230 & 0.368 \\
\hline Quality of accounting information & -0.487 & 0.451 & -0.002 & 0.145 \\
\hline $\begin{array}{c}\text { Interactive effect of quality accounting } \\
\text { information with institutional ownership }\end{array}$ & -0.441 & 0.388 & 0.007 & 0.091 \\
\hline Market risk premium & -0.238 & 0.131 & -0.167 & 0.039 \\
\hline $\begin{array}{c}\text { Size factor } \\
\text { Factor of market value to book value of } \\
\text { equity }\end{array}$ & -0.227 & 0.267 & 0.254 & 0.014 \\
\hline
\end{tabular}

Qualitative variables are variables whose values are zero and one so the use of dispersion and central indicators such as mean and standard deviation used for quantitative variables does not make sense for these types of variables. Therefore, frequency tables are used for such variables. Descriptive statistics of the qualitative variables are presented in Table 3.

Table 3. Descriptive statistics of qualitative variables

\begin{tabular}{|c|c|c|c|c|}
\hline $\begin{array}{c}\text { Qualitative } \\
\text { variable }\end{array}$ & Value & Frequency & Frequency & $\begin{array}{c}\text { Cumulative } \\
\text { frequency }\end{array}$ \\
\hline Institutional & 0 & 273 & $50.1 \%$ & $50.1 \%$ \\
ownership & 1 & 272 & $49.9 \%$ & 1 \\
\hline
\end{tabular}

As can be seen in Table 2, the mean cost of debt capital is 0.230 , which shows that between the year of the companies under review, the mean financial cost is 0.230 times the total facilities received, the greatest amount of which is for Iran Radiator Company in 2015.

Descriptive statistics on institutional ownership in Table 3 show that about $49.9 \%$ of the sample under review have institutional ownership more than the median of the whole sample.

The results of the descriptive statistics of other variables are consistent with the results of other studies.

\section{Inferential statistics}

Before analyzing the research data, the reliability (stationarity) of the dependent variable needs to be examined. The reliability of the research variables means that the mean and variance of the variables over time and the covariance of the variables over different years have been constant. As a result, using this variable in the model does not cause false regression. For this purpose, tests such as Levene, Lynn and Chou, Im, Pesaran \& Shin and Fisher can be used. For this purpose, the Fisher test is used, and the result of this test is presented in Table 4.

Table 4. Results of the stationarity test for the model variables 


\begin{tabular}{|l|l|l|c|}
\hline Cost of capital debt & 418.464 & 0.000 & $\begin{array}{c}\mathrm{H}_{0} \text { is rejected } \\
\text { (stationarity is confirmed) }\end{array}$ \\
\hline
\end{tabular}

The above results reject the null hypothesis that there is a single root; therefore, the stationarity of the dependent variable is confirmed.

Then, in order to estimate the research model, the appropriate method is first selected to fit the model. Between simple linear regression method, simple linear regression method with time factor, fixed effect panel method, random effects panel method and integrated data panel method, the appropriate method is chosen to fit the model and after fitting the model, the coefficients are estimated and their significance is reported. Then, the necessary tests are discussed separately to determine the appropriate method for estimating the research models and the test results of the hypotheses.

\section{Determining the appropriate method for estimating the research model}

The research hypotheses are estimated using the following model as panel data, and if the coefficient of accounting information quality $\left(\beta_{1}\right)$ is significant at $95 \%$ confidence level, it indicates the relationship between quality of accounting information and cost of capital debt and the first hypothesis is accepted. If the coefficient of institutional ownership $\left(\beta_{2}\right)$ is significant at the 95\% confidence level, it indicates that there is a relationship between institutional ownership and cost of capital debt and the second hypothesis is accepted. If the coefficient of the interactive effect of institutional ownership with the accounting information quality $\left(\beta_{3}\right)$ is significant at $95 \%$ confidence level, it indicates that institutional ownership moderates the relationship between quality of accounting information and cost of capital debt and the third hypothesis is accepted.

Cost of Debt $\mathrm{it}_{\mathrm{t}}=\beta_{0}+\beta_{1} \mathrm{AQ}_{\mathrm{it}-1}+\beta_{2} \mathrm{IQ}_{\mathrm{t}}+\beta_{3} \mathrm{AQ}_{\mathrm{t}-1} \times \mathrm{IQ}_{\mathrm{it}}+\beta_{4} \mathrm{r}_{\mathrm{m}, \mathrm{t}}+\beta_{5} \mathrm{SMB}_{\mathrm{t}}+\beta_{6} \mathrm{HML}_{\mathrm{t}}+\varepsilon_{i t}$

F-Limer test between the integrated panel method and the fixed effects panel

Table 5. F-Limer Test (Selecting the appropriate method between the integrated panel method and the fixed effects panel)

\begin{tabular}{|c|c|c|c|}
\hline Null hypothesis $\left(\mathbf{H}_{\mathbf{0}}\right)$ & $\begin{array}{c}\mathbf{f}- \\
\text { statistics }\end{array}$ & p-value & Test result \\
\hline $\begin{array}{c}\text { The use of integrated panel method is } \\
\text { preferable to fixed effects panel } \\
\text { method }\end{array}$ & 183.760 & 0.000 & $\begin{array}{c}\mathrm{H}_{0} \text { is rejected } \\
\text { (Fixed effects panel method is } \\
\text { better) }\end{array}$ \\
\hline
\end{tabular}

As can be seen, the p-value of this test is less than 0.05 at the significance level of $5 \%$. Therefore, the H0 hypothesis (integrated panel model) of the test is rejected at $95 \%$ confidence level and the H1 hypothesis (fixed effects panel model) is not rejected, indicating that the fixed effects panel model can be used.

\section{Hausman test}

Now, the more appropriate model should be selected between the fixed effects and random effects models using the Hausman test.

Table 6. Hausman test (choosing the appropriate method between fixed effects panel and random effects panel)

\begin{tabular}{|c|c|c|c|}
\hline Null hypothesis $\left(\mathbf{H}_{\mathbf{0}}\right)$ & $\begin{array}{c}\text { Chi-square } \\
\text { statistic }\end{array}$ & p-value & Test result \\
\hline $\begin{array}{c}\text { The use of random effects panel } \\
\text { method is preferable to fixed } \\
\text { effects method. }\end{array}$ & 4.454 & 0.485 & $\begin{array}{c}\mathrm{H}_{0} \text { is not rejected } \\
\text { (Random effects method is } \\
\text { better) }\end{array}$ \\
\hline
\end{tabular}

According to the results of the Hausman test, because the P-value of the test is more than $5 \%$, so the random effects panel method is more appropriate. 
To use panel methods, its underlying hypotheses should be examined. If only one of the underlying hypotheses is not established, the generalized model should be used and not all hypotheses need to be performed.

The first underlying hypothesis indicate that the errors have a normal distribution. The Jarque-Bera test is used to check if the errors are normal. As can be seen in Table 7, the significance level of the Jarque-Bera test is less than 5\%, so the null hypothesis is rejected and normality of the model errors are rejected.

The second underlying hypothesis of using the panel method is that the residuals of the self-correlation model do not exist. The Watson-Durbin test is used to check self-correlation of the model errors. Given that the Watson-Durbin statistic is within the acceptable range of 1.5 to 2.5 , independence of the residuals is accepted.

The third underlying hypothesis is that the error variance is constant. To check homoscedasticity of the model errors, the likelihood-ratio test is used, the null hypothesis of which indicates that the variance of errors is constant and in the alternate hypothesis the variance of errors is not constant. As shown in Table 7, given that the P-value of the Breusch-Pagan test is less than $5 \%$, the null hypothesis is rejected and the assumption that variance of the errors is constant is rejected.

Due to the rejection of the two underlying hypotheses of regression (normality and homoscedasticity), to fit the model into the data, the random panel model should be used in a generalized way. The results of estimating the model coefficients and their significance test are presented in Table 4-6.

Table 7. Results of estimating the model coefficients and their significance test

\begin{tabular}{|c|c|c|c|c|}
\hline Variables & Coefficients & $\begin{array}{l}\text { Standard } \\
\text { deviation }\end{array}$ & t statistic & p-value \\
\hline$y$-intercept & 0.149948 & 0.037638 & 3.983929 & 0.0001 \\
\hline $\begin{array}{c}\text { Quality of accounting } \\
\text { information }\end{array}$ & 0.039044 & 0.015794 & 2.472064 & 0.0137 \\
\hline Institutional ownership & -0.015027 & 0.004143 & -3.626706 & 0.0003 \\
\hline $\begin{array}{c}\text { Interactive effect of } \\
\text { accounting information } \\
\text { quality with institutional } \\
\text { ownership }\end{array}$ & -0.052469 & 0.028552 & -1.837653 & 0.0667 \\
\hline Market risk premium & 0.204846 & 0.157478 & 1.300788 & 0.1939 \\
\hline Size factor & 0.048325 & 0.164747 & 0.293326 & 0.7694 \\
\hline $\begin{array}{l}\text { Factor of market value to } \\
\text { book value of equity }\end{array}$ & 0.149948 & 0.037638 & 3.983929 & 0.0001 \\
\hline \multirow{4}{*}{$\begin{array}{l}\text { Overall results of the } \\
\text { model }\end{array}$} & Fisher's F-statistic & 9.365 & p-value & 0.000 \\
\hline & $\begin{array}{c}\text { Likelihood-ratio } \\
\text { statistic }\end{array}$ & 1479.995 & p-value & 0.000 \\
\hline & Jarque-Bera statistic & 268747.001 & p-value & 0.000 \\
\hline & $\begin{array}{l}\text { Adjusted coefficient } \\
\text { of determination }\end{array}$ & 0.071 & $\begin{array}{l}\text { Watson-Durbin } \\
\text { statistic }\end{array}$ & 1.665 \\
\hline
\end{tabular}

As can be seen in Table 7, p-value of Fisher's F-statistic indicates the significance of the total regression model, and the coefficient of determination of the model is about 7\%, which shows that $7 \%$ of the variation in the dependent variable (cost of capital debt) is explained by independent and control variables. 


\section{The first hypothesis test}

The first research hypothesis states that there is a significant relationship between quality of accounting information and cost of capital debt. To check significance of the coefficients of the independent variables in each model, t-statistic is used to study the effect of the independent variable. As can be seen in Table 4-6, the coefficient of quality of accounting information is 0.039 and its p-value is 0.013 , which is less than $5 \%$, so the coefficient of quality of accounting information is significant. This means that quality of accounting information affects cost of capital debt. The positive coefficient shows that as quality of accounting information increases (due to the inverse relationship between level of voluntary discretionary accruals and quality of accounting information), cost of capital debt decreases. Therefore, the first hypothesis of the research is confirmed.

\section{The second hypothesis test}

The second research hypothesis states that there is a significant relationship between institutional ownership and cost of capital debt. To check significance of the coefficients of the independent variables in each model, t-statistic is used to study the effect of the independent variable. As can be seen in Table 7, the coefficient of institutional ownership is -0.015 and its p-value is 0.00 , which is less than $5 \%$, so the coefficient of institutional ownership is significant. This means that institutional ownership affects cost of capital debt. The negative coefficient shows that as institutional ownership increase, cost of capital debt decreases. Therefore, the second hypothesis of the research is confirmed.

\section{The third hypothesis test}

The third research hypothesis states that institutional ownership moderates the relationship between quality of accounting information and cost of capital debt. To check significance of the coefficients of the independent variables in each model, t-statistic is used to study the effect of the independent variable. As can be seen in Table 7, the coefficient of interactive effect of accounting information quality with institutional ownership is -0.052 and its p-value is 0.066 , which is higher than $5 \%$, so the coefficient of interactive effect of accounting information quality with institutional ownership is not significant. This means that institutional ownership has not been able to moderate the relationship between quality of accounting information and cost of capital debt. Therefore, the third hypothesis of the research is rejected.

The summary of statistical test results of the research hypotheses is presented in Table 8 .

Table 8. Summary of results of the research hypotheses

\begin{tabular}{|c|c|c|}
\hline & Research hypotheses & Result \\
\hline $\begin{array}{c}\text { The first } \\
\text { hypothesis }\end{array}$ & $\begin{array}{c}\text { There is a significant relationship between quality of accounting } \\
\text { information and cost of capital debt. }\end{array}$ & Confirmed \\
\hline $\begin{array}{c}\text { The } \\
\text { second } \\
\text { hypothesis }\end{array}$ & $\begin{array}{c}\text { There is a significant relationship between institutional ownership and } \\
\text { cost of capital debt. }\end{array}$ & Confirmed \\
$\begin{array}{c}\text { The third } \\
\text { hypothesis }\end{array}$ & $\begin{array}{c}\text { Institutional ownership moderates the relationship between quality of } \\
\text { accounting information and cost of capital debt. }\end{array}$ & Rejected \\
\hline
\end{tabular}

\section{Conclusion}

First, descriptive statistics related to research data and variables were calculated and presented. Then, in order to examine the relationship between institutional ownership and quality of accounting information and cost of capital debt and to examine the moderating role of institutional ownership in the relationship between quality of accounting information and cost of capital debt, regression analysis was presented. Also, in the regression analysis, the generalized regression model was fit, and the coefficients of regression variables were estimated. In addition, the test of zero regression coefficients for the significance of the model and each of the variables was 
performed. The test results of the research hypotheses showed that there is a significant relationship between institutional ownership and quality of accounting information and cost of capital debt, but institutional ownership has not been able to moderate the relationship between quality of accounting information and cost of capital debt.

According to the results of the analysis in this study and the results of other studies, and considering that panel data is often abnormal, non-parametric statistics are more appropriate for the data of this study.

\section{Suggestions for future studies}

- Identifying other variables besides the institutional ownership variable as a factor affecting cost of capital and quality of accounting information.

- Determining the effect of institutional ownership as an intervening variable in the relationship between quality of accounting information and cost of capital.

\section{References}

Alimardi, N. (2016). Investigating the Impact of Institutional Ownership and Company Debts on Auditing Quality in Iran's Capital Market. International Conference on Industrial Engineering and Management, Tehran, Permanent Secretariat of the Conference.

Anagnostopoulou, S.C., \& Tsekrekos, A.E. (2015). Accounting quality, information risk and implied volatility around earnings announcements. Journal of International Financial Markets, Institutions and Money, 34, 188-207.

Garmei, D., \& Asadollahi, S.Y. (2017). Investigating the effect of institutional ownership on the relationship between the quality of accounting information and investment options of the company, the first conference on accounting, management and economics with the dynamic approach of national economy, Malayer, Islamic Azad University, Malayer branch.

Gray, P., Koh, P.S., \& Tong, Y.H. (2018). Accruals quality, information risk and cost of capital: Evidence from Australia. Journal of Business Finance \& Accounting, 36(1-2), 51-72.

Hassanvand, R. (2016). Accounting information, cost of capital and excess stock returns with emphasis on the role of earnings quality in listed companies. 6th International Conference on Accounting and Management and 3rd Conference on Entrepreneurship and Open Innovation, Tehran, Mehr Ishraq Conventioneers.

Hsieh, T. Y., Shiu, Y. M., \& Chang, A. (2019). Does institutional ownership affect the relationship between accounting quality and cost of capital? A panel smooth transition regression approach. Asia Pacific Management Review.

Jafari, S., \& Mottaqi, A.A. (2016). Institutional Ownership and Returns Management: The Moderating Role of Audit Quality. First International Conference on Modern Paradigms of Intelligent Business and Organizational Management, Tehran, Shahid Beheshti University.

Karanovic, G., \& Gjosevska, B. (2016). Application of fuzzy logic in determining cost of capital for the capital budgeting process. Procedia Economics and Finance, 3, 78-83.

Qatebi, M., \& Shamshiri, I. (2017). Investigating the Relationship between Institutional Ownership, Management Property and Cost of Capital of Companies Listed on Tehran Stock Exchange, International Conference on Management, Business and Accounting, Tehran, Permanent Secretariat of the Conference.

Sun, J., Ding, L., Guo, J. M., \& Li, Y. (2016). Ownership, capital structure and financing decision: evidence from the UK. The British Accounting Review, 48(4), 448-463. 